ISSN 1112-9867

Available online at http://www.jfas.info

\title{
CHARACTERIZATION STUDY OF INDUSTRIAL WASTE GLASS AS STARTING MATERIAL IN DEVELOPMENT OF BIOACTIVE MATERIALS
}

\author{
H. A. Samad* and R. A. Rashid \\ Mineral Research Centre, Minerals and Geoscience Department Malaysia, 31400 Ipoh, Perak, \\ Malaysia
}

Published online: 10 November 2017

\begin{abstract}
In present study, an industrial waste glass was characterized and the potential to assess as starting material in development of bioactive materials was investigated. A waste glass collected from the two different glass industry was grounded to fine powder. The samples were characterized using X-ray fluorescence (XRF), pycnometer and inductively couple plasma (ICP). The XRF result indicates both waste glass (WG1 and WG2) are the glass made based SLS glass composition and the density values were in the range of commercial SLS glass. Results from ICP showed both waste glass has contains of heavy metal trace elements that exceeds the allowable concentration level as per standard ASTM F1538-03. Obviously from this study, these twotypes of waste glass were not suitable for use as starting material as no compromise against the toxic elements are allowed for use in the human body.
\end{abstract}

Keywords: waste glass; soda lime silica glass; biomaterials.

\section{INTRODUCTION}

Biomaterials field have been improved for new medical applications. A biomaterial can be defined by their function as a material in contact with living tissue, used to the treatment of disease or injury, to improve human health by restoring the function of tissue and organs in the body [1].Bioactive materials is one of the classification of biomaterials, which elicits a

Author Correspondence, e-mail: hamizah@jmg.gov.my

doi: http://dx.doi.org/10.4314/jfas.v9i6s.27 
specific biological response at the interface of the material which results in the formation of bonding between the body tissues and the material. The example of bioactive materials such as Bioglass ${ }^{\circledR}$, apatite-wollastonite $(\mathrm{A}-\mathrm{W})$ glass ceramic, synthetic hydroxyapatite (HA) and tricalcium phosphate (TCP). In bioactive glass and glass ceramics, bone bonding was first observed for certain compositional besides than the biocompatibility [2].

Majority of the bioactive glass and glass ceramic are based on the Bioglass ${ }^{\circledR} 45 \mathrm{~S} 5$ which consists 45 wt.\% $\mathrm{SiO}_{2}, 24.5$ wt.\% $\mathrm{Na}_{2} \mathrm{O}, 24.5$ wt.\% $\mathrm{CaO}$ and 6 wt.\% $\mathrm{P}_{2} \mathrm{O}_{5}[2]$. The main characteristics of this kind of bioactive glass is its highly reactive surface when immersed in human plasma or a similar solution. It has been found that a partial dissolution of the bioactive glass surface takes place, resulting in the formation of a silica-rich gel layer and subsequently the precipitation of a calcium phosphate layer on the bioactive material occurs. However, bioactive glasses have a drawback which poor mechanical strength restricting their application as load-bearing implants. To improve mechanical properties, the glasses are exposed to heat treatment which may influence not only the microstructure and mechanical properties but also their biological activity [2-3].

Abundance of waste glass products such as bottles, drinking glass, windows and containers for storing consumables disposed by communities has huge environment impacts which lead to serious problems. Compared to many other types of waste, glass is unique because it can be $100 \%$ recycled. However, glass recycling in Malaysia is still in its infancy. Only less than $30 \%$ of new bottles are made from recycled glass compared to $80 \%$ in Thailand and $60-70 \%$ in Europe [4]. Avast majority of glass is stills ends up at landfills. Soda-lime- silicate (SLS) waste glass is the most common type of glass consumer used for food containers with the major chemical compositions of SLS waste glass are basically $\mathrm{SiO}_{2}$ in the range of 70 to 80 weight $\%$ and other oxide such as $\mathrm{CaO}$ in the range of 9 to 11 weight $\%[2-3,5]$.

Due to the high content of $\mathrm{SiO}_{2}$, SLS waste glass is being a common starting material in making of glass and glass ceramics for various applications. Previous research by Thoo and co-workers have reported that waste glass is suitable to be utilized in production of glass ionomer cement (GIC) for dental application [6]. SLS waste glass have been used in other fields of study as reported by [7]. By adding the SLS waste glass in stoneware tile, the compressive strength has increased in terms of mechanical properties. Besides, SLS waste glass also has been used in producing vitreous ceramics [8]. However, there are limited studies reported the use of SLS waste glass in development of bioactive glass ceramic for bone implant [9-12]. For this purpose,SLS waste glass will be used as a main source of silica. Hence, in this study a waste glass from Malaysian glass industries will be characterized and 
investigated to see their potential in attempts for the development of bioactive glass ceramics based materials.

\section{MATERIALS AND METHOD}

\subsection{Materials}

The waste glass was collected from the two different glass industry in Malaysia. There are labelled as WG1 and WG2. WG1 is a type of safety glass which formed in laminated and tempered glass with the flat shape. While, WG2 is a type of processed glass in a cullet form to be supply as material in the glass industries. The received of the cullet glass are in angular shape and elongated particles. The waste glass,WG1 and WG2 are shown as in Fig. 1 and Fig. 2 respectively. Both waste glasses were crushed and milled using mortar grinder (Retsch RM100, Germany) for 2 hours to form a glass powder.

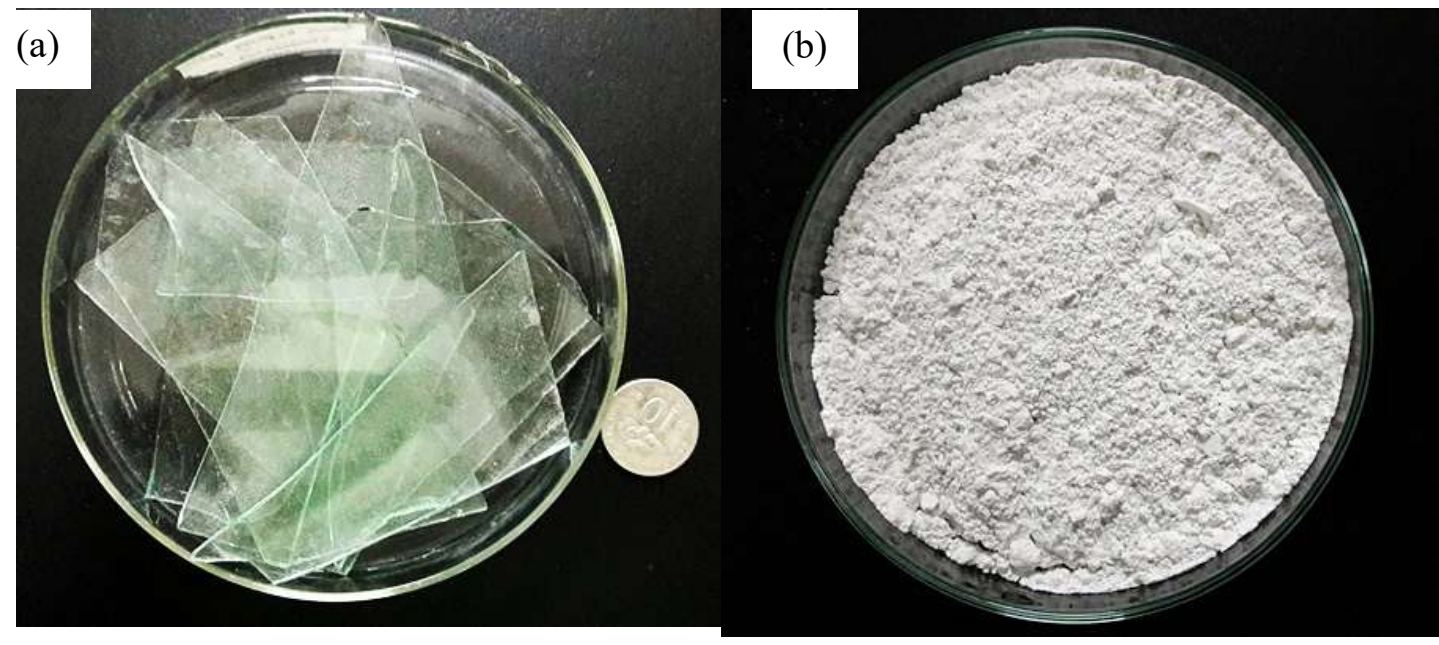

Fig.1. AWG1 sample (a) as received (b) in powder form after grinding

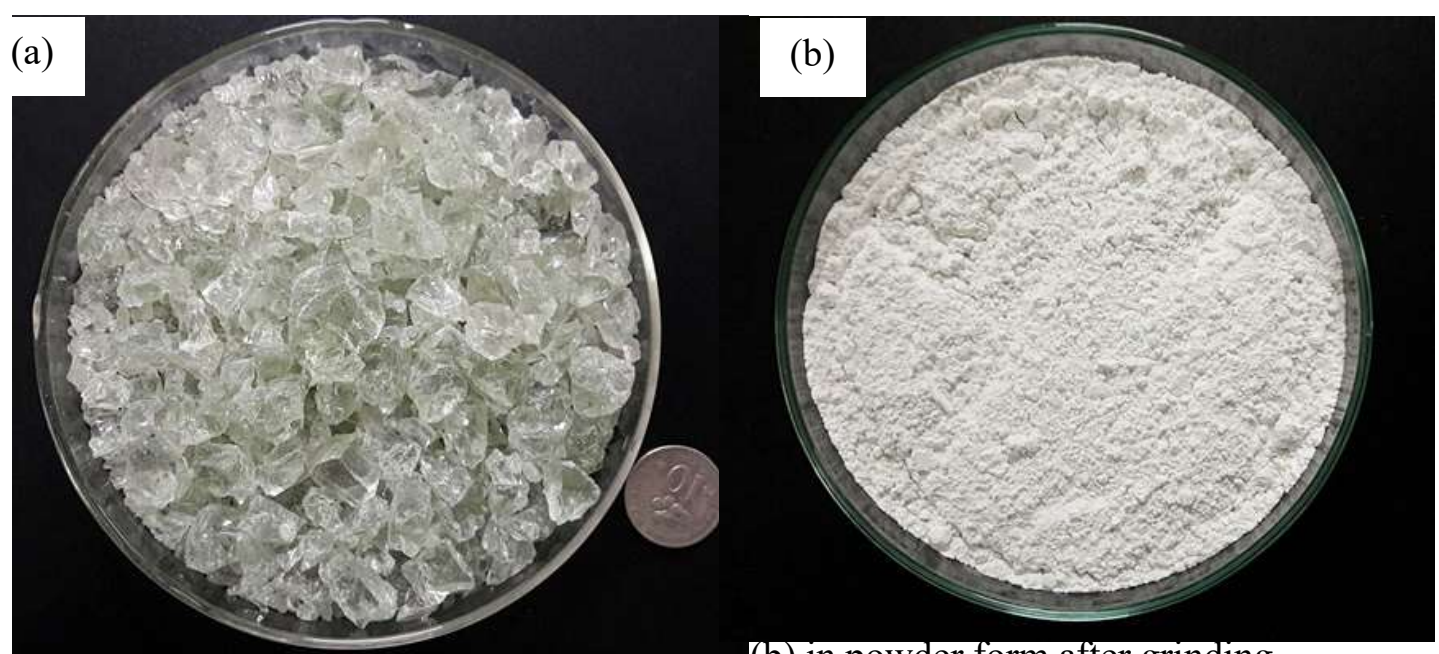

(b) in powder form after grinding 


\subsection{Characterization}

This work deal with the characterization of waste glass powder by X-ray fluroscence(XRF), X-ray diffraction (XRD), pycnometer and inductively couple plasma optical emission spectrometer (ICP-OES) equipment.

The waste glass was characterized using XRF (Model XRF-1800, Shimadzu Corporation, Kyoto, Japan) andXRD (Model D8 Advance, Bruker, Germany) to determine its chemical composition and the main phases, respectively. While, the density of waste glass powder was determined using pycnometer (Model NOVA 1000, Quantachrome, USA). In order to evaluate the heavy metal content, the glass powder were subjected to analysis using ICP-OES (Model Optima 5300 OV, Perkin Elmer, USA).

\section{RESULTS AND DISCUSSION}

The data of chemical composition of the WG1 and WG2 are summarized in Table 1.Silicon dioxide $\left(\mathrm{SiO}_{2}\right)$ was the predominant oxide, followed by sodium oxide $\left(\mathrm{Na}_{2} \mathrm{O}\right)$ and calcium oxide $(\mathrm{CaO})$ as the typical soda-lime-silica glass components. The waste glass contains very minor amounts of impurities in the form of iron and alkaline less than $2 \%$. $\mathrm{SiO}_{2}$ was acted as the forming agent of the glass network. From the result, $\mathrm{SiO}_{2}$ was shown the content is about $70 \%$ and $\mathrm{Na}_{2} \mathrm{O}$ and $\mathrm{CaO}$ is about $13 \%$ and $9 \%$ respectively. Generally, the chemical composition of both samples not much vary according to the commercialSLSglass content. 
Table 1. XRF analysisof theindustrial waste glass

\begin{tabular}{|c|c|c|c|}
\hline \multirow[t]{2}{*}{ Oxides } & \multicolumn{3}{|r|}{ Composition(wt\%) } \\
\hline & WG1 & WG2 & Approximate Limits Commercial SLS Glass \\
\hline $\mathrm{SiO}_{2}$ & 68.52 & 69.31 & $63-81$ \\
\hline $\mathrm{Na}_{2} \mathrm{O}$ & 13.91 & 13.38 & $9-15$ \\
\hline $\mathrm{CaO}$ & 8.23 & 9.05 & $7-14$ \\
\hline $\mathrm{MgO}$ & 5.85 & 5.60 & $0-6$ \\
\hline $\mathrm{Al}_{2} \mathrm{O}_{3}$ & 1.49 & 1.56 & $0-2$ \\
\hline $\mathrm{Fe}_{2} \mathrm{O}_{3}$ & 0.88 & 0.29 & $0-0.6$ \\
\hline $\mathrm{K}_{2} \mathrm{O}$ & 0.44 & 0.45 & $0-1.5$ \\
\hline $\mathrm{TiO}_{2}$ & 0.26 & - & $0-0.8$ \\
\hline $\mathrm{F}$ & 0.20 & 0.21 & - \\
\hline $\mathrm{SO}_{3}$ & 0.18 & - & $0-0.3$ \\
\hline $\mathrm{ZrO}_{2}$ & 0.04 & 0.03 & - \\
\hline $\mathrm{PbO}$ & - & 0.09 & - \\
\hline $\mathrm{ZnO}$ & - & 0.03 & - \\
\hline
\end{tabular}

Fig.3 presented the XRD patterns of both SLS waste glass powder. From the figure obviously, the characteristic band of amorphous material of the glass is indicated by the XRD pattern which consist of only a broad and halo peak around the Bragg position at 2 theta $=29-30^{\circ}$. There is no presence of crystalline phases was showed from the patterns.

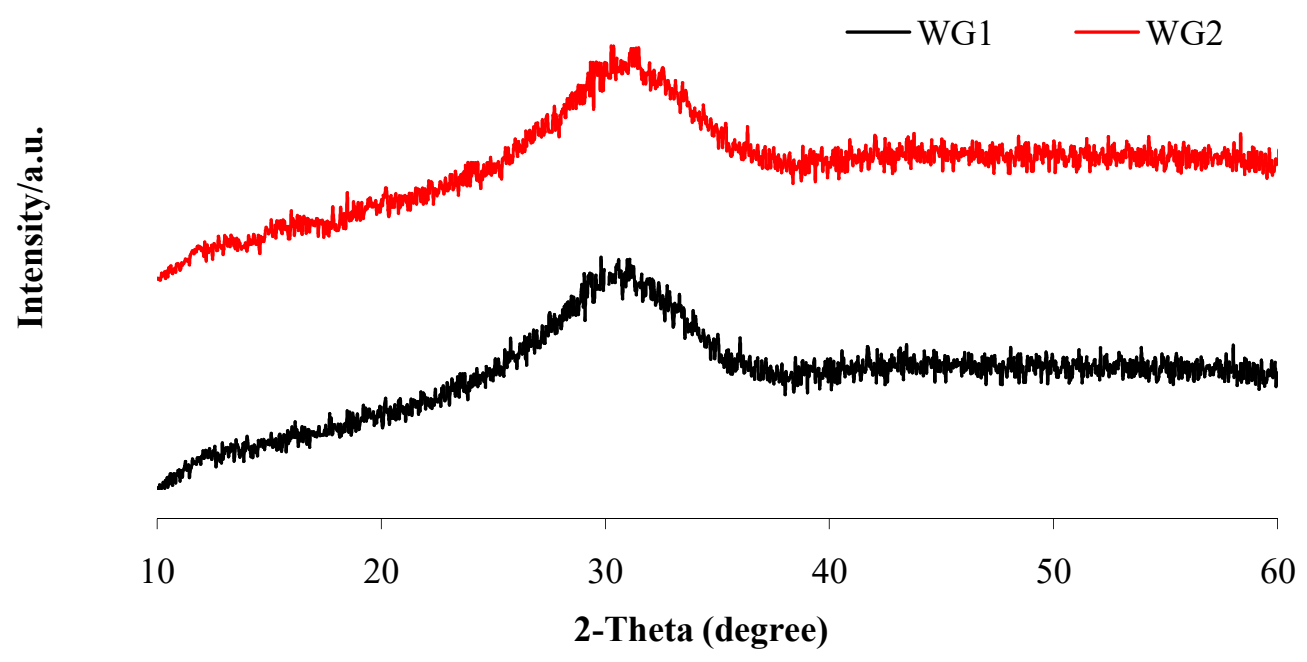

Fig.3.XRD patterns of soda lime silica waste glass 
Table 2 depicts the density of the waste glass, WG1 and WG2 at room temperature, $27^{\circ} \mathrm{C}$. The densities were around $2.50 \mathrm{~g} / \mathrm{cm}^{3}$ which are in the range of the density of commercial SLS glass.

Table 2.Densities of the waste glass samples

\begin{tabular}{cc}
\hline Sample & Density $\mathbf{g} / \mathbf{c m}^{\mathbf{3}}$ \\
\hline WG1 & 2.5792 \\
WG2 & 2.5570 \\
Commercial SLS glass & $2.50-2.58$
\end{tabular}

ICP analysis is important in order to detect the presence of heavy metal which refers to the toxic elements that adversely affect health including arsenic (As), cadmium (Cd) and lead $(\mathrm{Pb})$ and mercury $(\mathrm{Hg})$. The SLS waste glass powder was evaluated of heavy metals leach-out in accordance with the Standard Specification for Glass and Glass Ceramic Biomaterials for Implantation (ASTM F1538-03) [9]. Table 3 shows the result of ICP analysis for SLS waste glass has contains of heavy metals trace elements of $\mathrm{As}, \mathrm{Cd}$ and $\mathrm{Pb}$. While, no element of $\mathrm{Hg}$ was detected in samples of WG1 and WG2. From the analysis indicated that the only Cd had fulfilled the requirement of standard specification. $\mathrm{As}$ and $\mathrm{Pb}$ has exceeds the allowable concentration level. According to the standard specification, the permissible concentration levels of $\mathrm{As}, \mathrm{Cd}, \mathrm{Hg}$ and $\mathrm{Pb}$ should not exceed 3, 5, 30 and 5 ppm respectively.

Table 3. The impurity contents of heavy metal trace elements in SLS waste glass

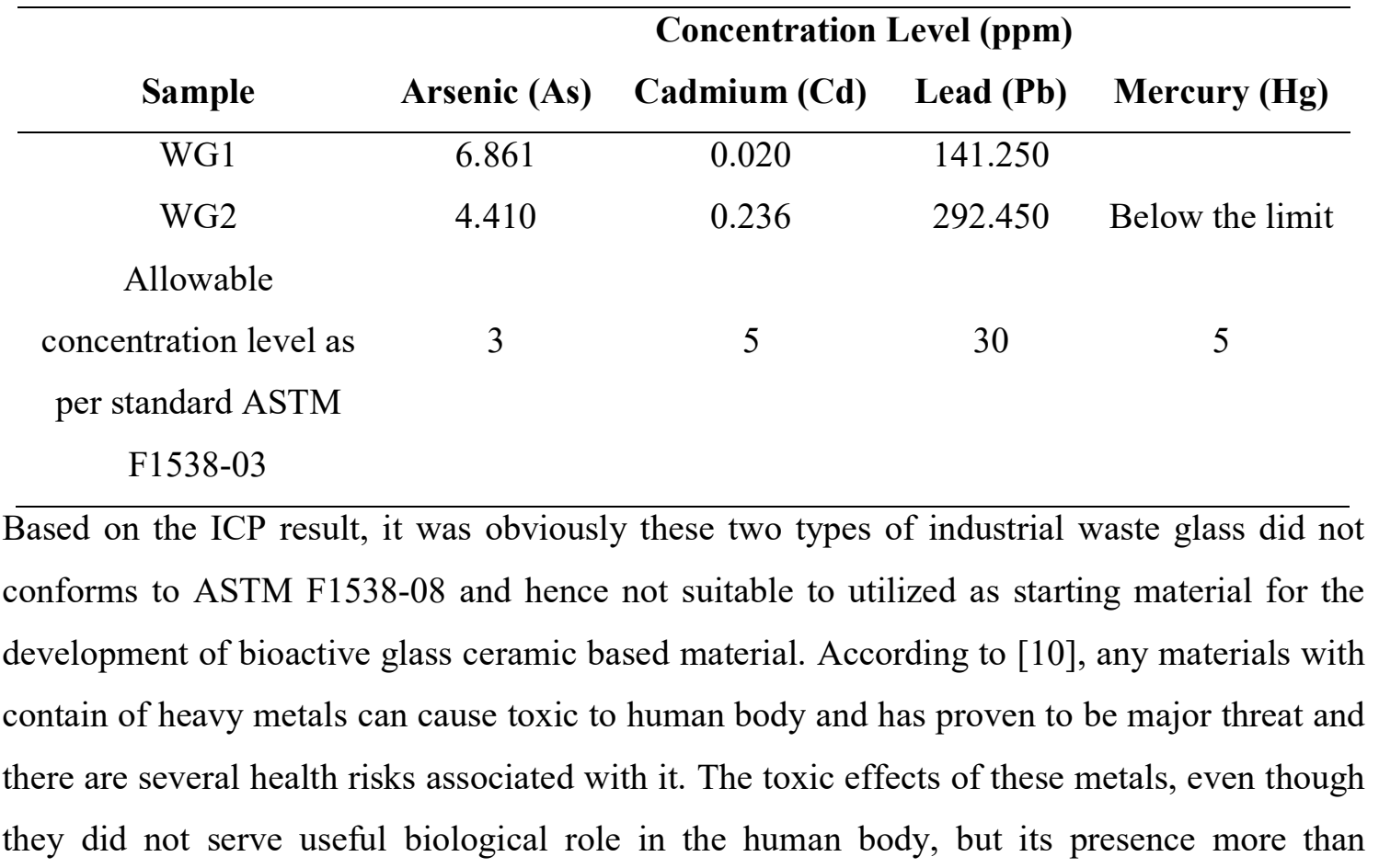


allowable limits are could give adverse effects by interferes the cell growth and may cause the death of cells in the human body.

\section{CONCLUSION}

This work deal with the waste glass in terms of physical and chemical characterization to evaluate their potential to be used as starting material in development of bioactive glass ceramic based material.

- From the result of XRD and XRF, it was confirmed that the waste glass was an amorphous soda-lime glass with the predominant oxide of silica.

- The ICP analysis results showed presence of toxic elements of As and $\mathrm{Pb}$ which exceeding the allowable concentration limit as per standard, hence did not met the requirement from specifications of ASTM F1538-03.

- Therefore, it can be concluded that these two Malaysian industrial waste glass are not suitable to be used as substitute raw material for development of bioactive glass ceramics as there is no compromise against the toxic elements are allowed for use in the human body.

\section{ACKNOWLEDGEMENTS}

The author would like to thank Director of Mineral Research Centre, Minerals and Geoscience Department Malaysia, all the staff of Advanced Materials Technology Section and for those involved either directly or indirectly to complete this study.

\section{REFERENCES}

[1] Park J. B., Lakes R. S.Biomaterials: An introduction. New York: Springer, 2007

[2] Cao W, Hench L L. Bioactive materials. Ceramic International, 1996, 22(6):493-507

[3] De Aza P N, De Aza A H, Pena P, De Aza S. Bioactive glass and glassceramics.BolletinSociedad Espanola Ceramica, 2007, 46(2):45-55

[4] Solid Waste Management Department (JPSPN). Kitarsemula. Putrajaya: JPSPN, 2015 http://jpspn.kpkt.gov.my/index.php/pages/view/131

[5] NourW M N, MostafaA A, Ibrahim D M. Recycled wastes as precursor for synthesizing wollastonite. Ceramics International, 2008, 34(1):101-105

[6] Francis T V W, Zainuddin N, Matori K A, Abdullah S A. Studies on the potential of waste soda lime silica glass in glass ionomer cement production. Advances in Materials Science and Engineering, 2013, 2013:1-6 
[7] Tucci A, Esposito L, Rastelli E, Palmonari C, Rambaldi E. Use of soda-lime scrap-glass as a fluxing agent in a porcelain stoneware tile mix. Journal of the European Ceramic Society, 2004, 24(1):83-92

[8] Marinoni N, D'Alessio D, Diella V, Pavese A, Francescon F. Effects of soda-lime-silica waste glass on mullite formation kinetics and micro-structures development in vitreous ceramics. Journal of environmental management, 2013, 124:100-107

[9] American Society for Testing and Materials (ASTM). ASTM F1538-03: Standard specification for glass and glass ceramic biomaterials for implantations.Pennsylvania: ASTM International, 2017

[10] Jaishankar M, Tseten T, Anbalagan N, Mathew B B, Beeregowda K N. Toxicity, mechanism and health effects of some heavy metals. Interdisciplinary Toxicology, 2014, $7(2): 60-72$

[11] Abbasi M, Hashemi B. Fabrication and characterization of bioactive glass-ceramic using soda-lime-silica waste glass. Materials Science and Engineering: C, 2014, 37:399-404

[12] $\mathrm{Lu} \mathrm{J,} \mathrm{Lu} \mathrm{Z,} \mathrm{Peng} \mathrm{C,} \mathrm{Li} \mathrm{X,} \mathrm{Jiang} \mathrm{H.} \mathrm{Influence} \mathrm{of} \mathrm{particle} \mathrm{size} \mathrm{on} \mathrm{sinterability,}$ crystallisation kinetics and flexural strength of wollastonite glass-ceramics from waste glass and fly ash. Materials Chemistry and Physics, 2014, 148(1):449-456

\section{How to cite this article:}

Samad H A, Rashid R A. Characterization study of industrial waste glass as starting material in development of bioactive materials. J. Fundam. Appl. Sci., 2017, 9(6S), 350-357. 